\title{
PEMBERDAYAAN PEREMPUAN MARGINAL MELALUI PROGRAM PENDIDIKAN KECAKAPAN HIDUP-PEREMPUAN (PKH-P)
}

\author{
A. Suhardi \\ STAIN Watampone, Jl. HOS. Cokroaminoto No. 1 Watampone \\ e-mail: suhardiandi@yahoo.co.id
}

\begin{abstract}
s:
This paper describes the empowerment of marginal women through women's life skill education program. Lack of access to education, economy, employment, public policy, basic rights, gender equality, politics, and health are the causes of women getting marginalized. Empowering women through life skills education are an effort to empower women through various activities. The result of program "PKH-P (Pendidikan Kecakapan Hidup-Perempuan" is behavior change, that is the increasing of knowledge, skill, and attitude of self. So that marginal women can help themselves to be more empowered and out of the condition of their marginality towards the quality of life and higher level of living welfare.
\end{abstract}

\section{Abstrak:}

Tulisan ini menguraikan tentang pemberdayaan perempuan marginal melalui program pendidikan kacakapan hidup perempuan. Kurangnya akses di bidang pendidikan, ekonomi, pekerjaan, kebijakan publik, pemenuhan hak-hak dasar, kesetaraan gender, politik, dan kesehatan merupakan penyebab perempuan semakin termarginalkan. Pemberdayaan perempuan melalui pendidikan kecakapan hidup merupakan upaya pemberdayaan perempuan melalui berbagai kegiatan. Hasil yang dicapai dari program PKH-P (Pendidikan Kecakapan Hidup-Perempuan" adalah perubahan perilaku, yaitu meningkatnya pengetahuan, kerampilan, dan sikap diri. Sehingga perempuan marginal mampu menolong dirinya sendiri untuk lebih berdaya dan keluar dari kondisi kemarginalannya menuju kualitas kehidupan dan tingkat kesejahteraan hidup yang lebih tinggi.

Kata kunci: pemberdayaan, perempuan marginal, pendidikan kecakapan hidup.

\section{PENDAHULUAN}

Satu dari dua puluh dua kelompok marginal di Indonesia disandang oleh perempuan, yaitu perempuan marginal. Kondisi marginal perempuan terjadi di banyak bidang kehidupan baik disektor publik maupun domestik. Pendidikan, ekonomi, pekerjaan, kebijakan publik, hak-hak dasar perempuan, kekerasan dalam rumah tangga, perdagangan manusia, kesetaraan gender, politik, dan kesehatan merupakan sebagian dari bidang kehidupan di dalamnya terbukti masih banyak memarginalisasikan perempuan. 
Di bidang kesehatan reproduksi, angka kematian ibu melahirkan masih relatif cukup tinggi. Hal tersebut sangat berkaitan pemenuhan hak akses terhadap layanan kesehatan perempuan belum mencukupi. Kebijakan di bidang pemenuhan layanan kesehatan perempuan khususnya yang terkait dengan fungsi reproduksi menyebabkan perempuan banyak yang tertinggal dalam pengetahuan dan belum mampu memberdayakan dirinya sendiri. Keterbatasan perempuan untuk mengakses sumber-sumber informasi kesehatan, meningkatkan pengetahuan, serta layanan kesehatan reproduksi perempuan menyebabkan perempuan masih tertinggal. Kontribusi perempuan di bidang ketenagakerjaan dan ekonomi juga masih jauh tertinggal dibanding dengan laki-laki.

Di bidang politik keterwakilan perempuan di lembaga legislatif sangat rendah, bahkan di lima provinsi di Indonesia pada periode 2009-2014, perempuan tidak terwakili di legislatif tingkat provinsi. Hal demikian mengakibatkan aspirasi perempuan rentan tidak terakomodir ketika legislatif menetapkan produk legislatif yang melibatkan perempuan sebagai subjek perundang-undnagan yang dilahirkan. Pemberdayaan perempuan secara simultan diharapkan dapat meningkatkan kemampuan (capability) dan kualitas hidupnya, keluarga dan masyarakat yang ditandai dengan meningkatnya aspek spiritualitas, sosial, pengetahuan dan keterampilan. Melalui pemberdayaan perempuan diharapkan dapat meningkatkan produktivitas perempuan, yang pada akhirnya akan bermuara pada terpenuhinya harkat dan martabat perempuan.

Pemenuhan hak-hak pendidikan yang menjadi hak dasar perempuan, terbukti masih terjadi ketimpangan sangat serius di negeri ini. Secara nasional angka rata-rata tingkat buta huruf penduduk perempuan masih jauh tinggi di banding laki-laki. Data statistik menunjukkan bahwa 30 kabupaten/kota di 13 provinsi di Indonesia rata-rata angka buta aksara yang disandang penduduk perempuan masih di atas rata-rata nasional.

Perempuan marginal adalah sebuah masalah. Kemarginalan penduduk perempuan sangat berpotensi akan menurunkan kemarginalan kepada generasi yang dilahirkan. Perempuan marginal sangat rentan mengalami masalah sosial, dan sangat beresiko secara sosial. Memberdayakan perempuan marginal melalui jalur pendidikan adalah sebuah keniscayaan. Pendidikan pemberdayaan perempuan merupakan instrumen untuk mobilisasi sosial baik vertikal maupun horisontal pada perempuan marginal. Menarik dan mengeluarkan 
perempuan dari kemarginalan yang dialami, menjadi pintu mulia untuk membantu perempuan lebih berdaya, bermartabat, baik secara sosial maupun ekonomi.

Rasional tersebut menjadi pertimbangan mendasar bahwa untuk mencegah makin termarginalkan, untuk mengeluarkan perempuan dari situasi marginal, memberdayakan perempuan merupakan pilihan bijaksana. Memberdayakan perempuan dalam segala aspek kehidupan menjadi pintu pembuka bagi perempuan untuk selanjutnya mampu memberdayakan dirinya sendiri. Sekurang-kurangnya empat kecakapan yang perlu dikembangkan melalui Program Pendidikan Kecakapan Hidup (PKH) Perempuan yang berorientasi pemberdayaan perempuan, sebagai instrumen memberdayakan perempuan marginal. Keempat kecakapan tersebut yaitu kecakapan personal, sosial, intelektual, dan kecakapan vokasional. PKH Perempuan merupakan bagian dari strategi pengentasan kemiskinan, ketertinggalan pendidikan yang dialami perempuan marginal.

\section{PEMBAHASAN}

\section{A. Permasalahan Perempuan di Bidang Ekonomi}

Permasalahan perempuan di bidang ekonomi tidak terlepas dari kemiskinan. Perempuan dalam kegiatan usaha secara umum terbagi dalam empat kelompok, yaitu perempuan tidak mampu berusaha karena beban kemiskinan; perempuan yang belum/tidak berusaha; perempuan pengusaha mikro; dan perempuan pengusaha kecil dan menengah.

Perempuan tidak mampu berusaha karena beban kemiskinan khususnya dalam pemenuhan pendidikan dan kesehatan, harus berusaha dengan segala cara dan berorientasi pada kebutuhan saat ini. Perempuan dalam keluarga miskin ini sulit untuk berpikir jernih dan terbuka dalam menata kehidupan masa depan. Sedangkan untuk perempuan yang belum/ tidak berusaha, dihadapi permasalahan sikap, budaya, pengetahuan dan penerapan. Perempuan tidak berusaha karena motivasi yang kurang walaupun sumberdaya yang dimilikinya sebenarnya cukup atau mampu. Di lain pihak, ada perempuan ingin tapi tidak memiliki pengetahuan atau ketrampilan untuk usaha.

Tiga pendekatan kemiskinan yaitu pendekatan kultural, struktural, dan alamiah, baik secara parsial maupun bersamaan dapat dipakai untuk menjelaskan penyebab kemiskinan di kalangan kaum perempuan, baik secara ekonomi, politik, sosial, dan budaya. Pertama, secara kultural sebagian masyakat kita masih dipengaruhi secara kuat oleh budaya tradisional yang berideologi patriarki. Yaitu fenomena ketimpangan struktural berupa keterbatasan kaum 
perempuan untuk memperoleh pendidikan, memperoleh akses ekonomi (misalnya bekerja untuk memperoleh penghasilan dan bukan sebatas menjalankan peran sebagai ibu rumah tangga), berorganisasi, dan lain sebagainya masih tetap berlaku. Kedua, kemiskinan struktural berekses pada timbulnya kemiskinan kultural dalam wujud rendahnya pendidikan dan keterampilan sebagian besar perempuan (terutama di perdesaan). Sementara itu, kemiskinan alamiah menjelaskan adanya sebagian kaum perempuan yang bersikap pasrah terhadap posisi dirinya dalam kehidupan rumah tangga dan masyarakat, karena secara sadar menyadari demikianlah kodratnya sebagai seorang perempuan. ${ }^{1}$ Fenomena penerimaan ini tidak hanya dijumpai di kawasan perdesaan, tetapi juga di perkotaan termasuk di kalangan perempuan terpelajar.

Sumber permasalahan yang menyebabkan kemiskinan bagi perempuan di Indonesia adalah budaya patriarki. Budaya ini penyebab terjadi diskriminasi, marginalisasi, pelecehan, ekploitasi, akibat sumber pembenaran terhadap sistem distribusi kewenangan, sistem pengambilan keputusan, sistem risorsi bias gender, sistem pembagian kerja, dan sistem pemilikan. ${ }^{2}$ Kemiskinan pada perempuan lebih ditafsirkan pada suatu kondisi ketiadaan access pada pilihan-pilihan yang seharusnya melekat di bidang sosial, politik, ekonomi, kebudayaan, dan lingkungan hidup. Konsep yang amat dekat dengan konsep kemiskinan adalah impoverishment (hal-hal yang menyebabkan perempuan menjadi miskin). Proses impoverishmentadalah sebuah proses aktif menghilangkan akses dan hak-hak dasar yang secara sistematik direproduksi dan diciptakan oleh sejumlah mekanisme global seperti kerusakan lingkungan hidup, kehancuran sumber daya rakyat, inflasi, pengangguran, budaya patriarki dan politik utang luar negeri. Proses inilah yang dikenal sebagai pelemahan (disenpowerment) ekonomi, ekologi, sosial, politik dan kebudayaan khususnya bagi kaum perempuan. $^{3}$

${ }^{1}$ Sulikanti Agusni,. Kebijakan dan Strategi Peningkatan produktifitas Ekonomi Perempuan, Kementerian Pemberdayaan Perempuan dan Perlindungan Anak Republik Indonesia, 2012, h. 13.

2 Susilorini, E. S. Evaluasi Program Pemberdayaan Ekonomi Perempuan Miskin di Kabupaten Ngawi, Media Soerje, Vol. 15 No. 2, Oktober 2014, ISSN: 1978-6239.

${ }^{3}$ Op.cit. h. 87. 


\section{B. Pemberdayaan Perempuan}

Secara etimologis pemberdayaan berasal dari kata dasar "daya" yang berarti "kemampuan". Berdasarkan dari keterangan tersebut maka pemberdayaan adalah kemampuan yang dimiliki oleh orang atau organisasi dalam upaya untuk membuat berdaya saing. ${ }^{4}$

Pemberdayaan adalah proses kepada masyarakat agar menjadi berdaya, mendorongatau memotivasi individu agar mempunyai kemampuan atau keberdayaan untukmenentukan pilihan hidupnya dan pemberdayaan harus ditujukan pada kelompokatau lapisan masyarakat yang tertinggal. ${ }^{5}$

Berdasarkan keterangan di atas maka pemberdayaan perempuan merupakan estimologidengan kata dasar daya yang berarti kemampuan untuk mendorong atau memotivasi individu agar mampu untuk menentukan pilihan hidup dan ditujukan pada kelompok atau lapisanmasyarkat yang tertinggal atau yang telah modern.

Pemberdayaan dimaknai sebagai proses menuju berdaya, proses untuk memperoleh daya dan atau proses pemberian daya dari pihak yang memiliki daya kepada yang kurang berdaya. Proses menunjuk kepada tindakan nyata yang dilakukan secara bertahap untuk mengubah kondisi masyarakat yang lemah menuju pada penguasaan pengetahuan, sikap dan keterampilan yang baik. ${ }^{6}$ Pemberdayaan adalah upaya memampukan (enabling) masyarakat kecil atau bawahan yang selama ini dianggap tidak atau kurang berperan agar meningkat dan memiliki kemampuan yang lebih baik sehubung dengan status dan peranan mereka di dalam sistem sosial. $^{7}$

Menurut Andi Hanindito menyatakan bahwa pemberdayaan perempuan dalam memperoleh akses dan kontrol terhadap semua sumber daya dalam seluruh aspek kehidupan. ${ }^{8}$ Mengarahkan rakyat, organisasi dan komunitas agar mampu menguasai

${ }^{4}$ Amin Kuncoro dan Kadar, Pengaruh Pemberdayaan Perempuan dan Peningkatan Sumber Daya Ekonomi Keluarga, Buana Gender, LP2M IAIN Surakarta, Vol. 1 No. 1, Januari-Juni 2016, ISSN: 2527-8096.

${ }^{5}$ Op.cit. h. 47.

${ }^{6}$ Ambar Teguh Sulistiyani. (2004). Kemitraan dan Model-Model Pemberdayaan. Yogyakarta: Gava Media.

${ }^{7}$ EliYuliawati. (2010). Pemberdayaan Kaum Perempuan dalam MenunjangPeningkatan Pendapatan Keluarga melalui Home Industry di Dusun Pelemadu, Desa Sriharjo, Kecamatan Imogiri, Kabupaten Bantul, DIY. Skripsi. Diakses dari eprints.uny.ac.id/7803/1/1-07404244051.pdf.padatanggal 18 Mei 2014.

${ }^{8}$ Andi Hanindito. (2011). Berdaya Bersama Perempuan Indonesia. Jakarta:Kementrian Sosial RI. 
kehidupannya. ${ }^{9}$ Upaya untuk membantu masyarakat dalam mengembangkan kemampuan sendiri sehingga bebas dan mampu untuk mengatasi masalah dan mengambil keputusan secara mandiri. ${ }^{10}$

Terdapat tiga alasan penting kenapa perempuan wajib diberdayakan dalam konteks pengentasan kemiskinan, yaitu: (1) karena perempuan mempunyai kepentingan yang sama dalam pembangunan, dan juga merupakan pengguna hasil pembangunan yang mempunyai hak sama dengan laki-laki, (2) perempuan juga memiliki kepentingan yang khusus sifatnya bagi perempuan itu sendiri dan anak-anak, yang kurang optimal jika digagas oleh laki-laki karena membutuhkan kepekaan yang sifatnya khusus terkait dengan keseharian, sosio kultural yang ada, dan (3) memberdayakan dan melibatkan perempuan dalam pembangunan, secara tidak langsung akan juga memberdayakan dan menularkan semangat positif kepada generasi penerusnya, yang pada umumnya dalam keseharian sangat lekat dengan sosok ibu. ${ }^{11}$

Pemberdayaan perempuan merupakan upaya untuk mewujudkan kesetaraan peran, akses, dan kontrol perempuan dan laki-laki di semua bidang pembangunan. Program-program pemberdayaan perempuan yang dilakukan oleh pemerintah dan masyarakat selama ini merupakan upaya untuk senantiasa mewujudkan terciptanya dan terdistribusinya manfaat pembangunan bagi laki-laki dan perempuan secara berimbang. Berbagai langkah dapat dilakukan untuk menciptakan kesetaraan laki-laki dan perempuan atau kesetaraan gender, antara lain dengan mengembangkan kewirausahaan keluarga sehingga dapat terwujud peran yang seimbang antara laki- laki dan perempuan dalam keluarga untuk bersama -sama membangun dan keluarga demi mencapai kesejahteraan keluarga. ${ }^{12}$ Meskipun upaya membangun kesetaraan gender tersebut telah dilakukan cukup lama, namun masih terdapat banyak hal dan sisi kehidupan yang belum mencerminkan adanya kesetaraan antara perempuan dan laki-laki. Kurangnya perhatian dan intensitas serta kesinambungan program

${ }^{9}$ Chatarina Rusmiyati. (2011). Pemberdayaan Remaja Putus Sekolah. Yogyakarta:B2P3KS Press.

${ }^{10}$ Agnes Sumartiningsih. (2004). Pembangunan Masyarakat Desa melalui InstitusiLokal. Yogyakarta: Aditya Media.

${ }^{11}$ Agung U, Titin H. Model Pemberdayaan Perempuan Miskin Melalui Pelatihan Kewirausahaan Berbasis Potensi Lokal di Kecamatan Wedi Kabupaten klaten. Jurnal Penelitian Humaniora, Vol. 19, No.2, Oktober 2014: $154-167$

${ }^{12}$ Ibid. h. 156. 
pemberdayaan perempuan merupakan salah satu penyebab belum terciptanya kesetaraan gender. Oleh karena itu, diperlukan upaya yang lebih giat, intensif, sungguh-sungguh, dan berkesinambungan untuk membangun kesetaraan gender melalui program-program pemberdayaan perempuan.

Mayoux, (2005a) menyatakan bahwa terdapat lima unsur utama yang perlu diperhatikan dalam proses pemberdayaan perempuan, yaitu sebagai berikut: ${ }^{13}$

\section{Welfare (Kesejahteraan)}

Aspek ini dapat dikatakan salah satu aspek yang penting dalam upaya peningkatan pemberdayaan perempuan. Tidak dapat dipungkiri bahwa dalam akses terhadap kesejahteraan, perempuan menempati posisi yang tidak menguntungkan. Kesejahteraan ini dibagi ke dalam tiga unsur utama berikut: Partisipasi ekonomi perempuan merupakan hal yang penting tidak hanya mengurangi levelkemiskinan pada perempuan, melainkan pula sebagai langkah penting untuk meningkatkan pendapatan rumah tangga dan mendorong pembangunan ekonomi negara secara keseluruhan. Sementara pencapaian pendidikan merupakan aspek paling fundamental dalam kegiatan pemberdayaan perempuan, tanpa memperoleh pendidikan yang memadai, perempuan tidak mampumengakses pekerjaan sektor formal, mendapatkan upah yang lebih baik, berpartisipasi dalam pemerintahan dan mencapai pengaruh politik. Kesehatan dan kesejahteraan merupakan sebuah konsep yang terkait dengan perbedaan substansial antara perempuan dan laki-laki dalam mengakses nutrisi yang cukup, kesehatan, fasilitas reproduksi, dan untuk mengemukakan keselamatan fundamental dan integritas seseorang. ${ }^{14}$

Pendidikan, pekerjaan, dan kepemilikan hak perempuan memberikan pengaruh yang kuat untuk meningkatkan kemampuan mereka untuk menguasai lingkungan mereka dan memberikan kontribusi bagi pembangunan ekonomi. Partisipasi ekonomi tidak hanya berhenti pada meningkatnya jumlah perempuan bekerja, melainkan pula kesetaraan dalam pemberian upah. $^{15}$

\footnotetext{
${ }^{13}$ Mayoux, Linda. (2005.a). Gender Equity, Equality, and Women's Empowerment. Principle, Development and Framework. Aga Khan Foundation. Diakses dari situs http://www.genfinances.net

${ }^{14}$ Claros, Augusto Lopez dan Saadia Zahidi. 2005. Woman Empowerment : Measuring The Global Gender Gap. Worl Economic Forum. Diakses dari situs : www.weforum.org

${ }^{15}$ Op.cit. h. 105.
} 


\section{Access (Akses)}

Dalam bahasa Longwe, akses diartikan sebagai kemampuan perempuan untuk dapat memperoleh hak/akses terhadap sumber daya produktif seperti tanah, kredit, pelatihan, fasilitas pemasaran, tenaga kerja, dan semua pelayanan publik yang setara dengan perempuan. Akses terhadap teknologi dan informasi juga merupakan aspek penting lainnya. Melalui teknologi dan informasi, perempuan dapat meningkatkan produktivitas ekonomi dan sosial mereka dan mempengaruhi lingkungan tempat ia tinggal. Tanpa akses, pemahaman, serta kemampuan untuk menggunakan teknologi informasi, perempuan miskin jauh lebih termarjinalisasi dari komunitasnya, negaranya, dan bahkan dunia.

\section{Consientisation (Konsientisasi)}

Pemahaman atas perbedaan peran jenis kelamin dan peran gender.

\section{Participation (Partisipasi)}

Kesetaraan partisipasi perempuan dalam proses pembuatan keputusan, pembuatan kebijakan, perencanaan, dan administrasi. Partisipasi ini merujuk pada keterwakilan perempuan yang setara dalam struktur pembuatan keputusan baik secara formal maupun informal, dan suara mereka dalam penformulasian kebijakan mempengaruhi masyarakat mereka. ${ }^{16}$

Berdasarkan beberapa pengertian di atas maka pemberdayaan dapat diartikan sebagai upaya untuk memotivasi dan membangkitkan kesadaran akan potensi masyarakat yang dimiliki serta berupaya untuk mengembangkannya agar mampu baik secara fisik, mental dan pikiran untuk mencapai kesejahteraan sosial hidupnya. Pemberdayaan dimaknai sebagai sebuah proses yang menunjuk pada kelompok lemah khususnya perempuan untukmemperoleh keterampilan, pengetahuan,dan memiliki akses terhadap sumber-sumber produktif yang memungkinkan mereka dapat meningkatkan pendapatan, memperoleh barang dan jasa serta berpartisipasi dalam proses pembangunan.

Melalui proses pemberdayaan diasumsikan bahwa perempuan di dalam kelompok sosial masyarakat terbawah sekalipun bisa terangkat dan muncul menjadi bagian masyarakat menengah ke atas. Konsep pemberdayaan perempuan menempatkan perempuan khusunya ibu rumah tangga sebagai subjek untuk mengembangkan diri dan mengarahkan mereka untuk tumbuh dan berkembang menjadi masyarakat berdaya. Tujuan akhirnya adalah agar

\footnotetext{
${ }^{16}$ Ibid, h. 106
} 
perempuan memiliki kemampuan untuk melaksanakan program-program yang berupaya memperbaiki dan meningkatkan taraf kehidupannya serta mampu mengatasi kebutuhan dan masalah yang dihadapi berdasarkan sumber daya yang dimiliki. Jadi, pendekatan pemberdayaan perempuan dalam pembinaan kecakapan hidup/life skills adalah penekananpada pentingnya pemberdayaan perempuan yang mandiri sebagaisuatu sistem yang mengorganisir diri mereka sendiri.

\section{Program Pendidikan Kecakapan Hidup Perempuan}

Pendidikan Kecakapan Hidup (PKH) Perempuan adalah ikhtiar memberdayakan perempuan marginal melalui pendidikan. Perempuan marginal merupakan bagian dari masyarakat kurang beruntung yang mengalami masalah dan/atau sangat rentan menerima dampak resiko sosial yang diakibatkan oleh kondisi mereka yang marginal. Atas dasar pertimbangan tersebut maka pemberdayaan perempuan marginal melalui PKH Perempuan diarahkan sebagai tindakan yang bersifat memihak (affirmative action) yakni untuk menarik atau mengeluarkan perempuan dari keadaan marginal yang dialami. ${ }^{17}$

Upaya memberdayakan perempuan marginal melalui PKH Perempuan dirancang untuk mengenali, menggali, dan mengembangkan seoptimal mungkin potensi perempuan pada empat aspek kecakapan penting yaitu (i) kecakapan personal, (ii) kecakapan sosial, (iii) kecakapan intelektual, dan (iv) kecakapan vokasional. Hasil yang diharapkan melalui pembelajaran Program PKH Perempuan adalah perubahan perilaku, yaitu meningkatnya pengetahuan, kerampilan, dan sikap diri. Selanjutnya perempuan marginal mampu menolong dirinya sendiri untuk lebih berdaya dan keluar dari kondisi kemarginalannya menuju kualitas kehidupan dan tingkat kesejahteraan hidup yang lebih tinggi.

Perempuan marginal memiliki sejumlah keterbatasan yang membelenggu dan menyulitkan mereka dalam memperoleh, harkat dan martabat hidup yang wajar sebagimana warga masyarakat lainnya. Resiko yang lebih besar yakni adanya kegagalan kelompok ini dalam mempertahankan diri karena ketidakmampuannya memenuhi kebutuhan bertahan hidup. Pada keadaan seperti ini negara (pemerintah) wajib hadir untuk mencegah dan membantu kelompok marginal khususnya perempuan agar sanggup mengatasi keadaan Dik.Bindiktara.

${ }^{17}$ Dik.Bindiktara. (2016). Petunjuk Teknis Program Pendidikan Kecakapan HidupPerempuan. Jakarta: 
marginal yang dialami dan menarik mereka keluar dari kemarginalan. Inilah urgensi program PKH Perempuan sebagai upaya sistematis pemerintah untuk mengeliminir dampak dan resiko sosial yang lebih besar bagi para perempuan marginal. ${ }^{18}$

Peserta didik Program PKH Perempuan adalah perempuan dewasa dan marjinal. Jenis perempuan marjinal menurut Dik.Bindiktara terdiri dari: 1) Kepala keluarga perempuan, 2) Buta huruf Perempuan, 3) Drop Out SD/SMP/SMA/SMK Perempuan, 4) Miskin Perempuan, 5) Buruh Perempuan, dan 6) Akibat penyakit sosial (PSK, Tuna Wisma, dll). ${ }^{19}$

${ }^{18} \mathrm{Ibid}, \mathrm{h} .7$.

${ }^{19} \mathrm{lbid}$, h. 9. 
Tabel 1. Indikator Perempuan Marginal Calon Peserta Didik PKH Perempuan

\begin{tabular}{|c|c|c|c|}
\hline No & Aspek & Indikator Utama/Sub Indikator & Keterangan \\
\hline 1 & Pendidikan & $\begin{array}{l}\text { Pendidikan rendah (urutan } \\
\text { prioritas): } \\
\text { 1.1.Berkeaksaraan rendah } \\
\text { 1.2.Putus sekolah dasar } \\
\text { 1.3.Tamat sekolah dasar (setara) } \\
\text { 1.4.Tidak tamat SMP (setara) } \\
\text { 1.5.Tamat SMP (setara) } \\
\text { 1.6.Tidak tamat SMA (setara) }\end{array}$ & $\begin{array}{l}\text { Skala prioritas } \\
\text { calon peserta } \\
\text { didik PKH } \\
\text { Perempuan } \\
\text { ini sifatnya } \\
\text { berurutan }\end{array}$ \\
\hline 2 & Usia & 2.1. Usia 18-45 Tahun (dewasa) & $\begin{array}{l}\text { Terhitung pada } \\
\text { saat dilakukan } \\
\text { identifikasi calon } \\
\text { peserta didik }\end{array}$ \\
\hline 3 & $\begin{array}{l}\text { Status } \\
\text { Pekerjaan }\end{array}$ & $\begin{array}{l}\text { 3.1.Tidak memiliki pekerjaan tetap } \\
\text { 3.1.1. Pekerja rumah tangga (PRT) } \\
\text { 3.1.2. Perempuan pekerja migran; } \\
\text { 3.1.4. Buruh tidak tetap } \\
\text { 3.1.5. Calon TKI } \\
\text { 3.1.6. Pasca-tenaga kerja luar } \\
\text { negeri } \\
\text { 3.1.7. Korban/rentan korban } \\
\text { perdagangan manusia } \\
\text { 3.1.8. Korban/sedang mengalami } \\
\text { dampak pasca-bencana }\end{array}$ & $\begin{array}{l}\text { Terhitung } \\
\text { saat mulai } \\
\text { dilaksanakan } \\
\text { kegiatan } \\
\text { pembelajaran } \\
\text { PKH } \\
\text { Perempuan. }\end{array}$ \\
\hline & & $\begin{array}{l}\text { 3.2.Tidak berstatus sebagai } \\
\text { Pegawai Negeri Sipil (PNS), } \\
\text { atau Calon PNS; } \\
\text { 3.3.Tidak berstatus Anggota } \\
\text { Tentara Nasional Indonesia \& } \\
\text { Kepolisian RI; } \\
\text { 3.4.Tidak berstatus sebagai } \\
\text { pegawai Badan Usaha Milik } \\
\text { Negara/Daerah atau yang } \\
\text { sejenis; }\end{array}$ & \\
\hline 4 & $\begin{array}{l}\text { Status } \\
\text { Ekonomi }\end{array}$ & Tidak mampu (miskin) & \\
\hline 5 & $\begin{array}{l}\text { Geografis } \\
\text { Domisili }\end{array}$ & $\begin{array}{l}\text { 5.1. Pedesaan dan/atau perkotaan; } \\
\text { 5.2.Terpencil dan/atau terisolir, } \\
\text { 5.3.Terluar, terdepan, tertinggal }\end{array}$ & \\
\hline 6 & $\begin{array}{l}\text { Status } \\
\text { Sosial }\end{array}$ & $\begin{array}{l}\text { Perempuan penyandang dan/atau } \\
\text { rentan masalah sosial }\end{array}$ & \\
\hline
\end{tabular}


Tujuan pendidikan kecakapan hidup perempuan adalah: 1) Meningkatkan kualitas kecakapan personal, sosial, keterampilanvokasional, dan intelektual melalui peningkatan kemampuan keberaksaraan perempuan marginal; 2) Mereduksi potensi dampak resiko sosial kelompok perempuan marginal melalui diperolehnya keterampilan vokasional sebagai sarana meningkatkan pendapatan berbasis usaha mandiri atau berkelompok; 3) Memfasilitasi terciptanya situasi yang kondusif bagi perempuan marginal keluar dari kondisi marginal yang dialami menuju kehidupan yang lebih bermartabat, dan 4) Membangun mental mandiri dan wirausaha untuk pemberdayaan, harkat dan martabat perempuan marginal. ${ }^{20}$

Hasil yang ingin dicapai dalam penyelenggaraan Program Pendidikan Kecakapan Hidup Perempuan ini menurut Dik.Bindiktara adalah: 1) Tersedianya layanan informasi pada jalur pendidikan nonformal berupa buku maupun non-buku yang tersedia pada Program Pendidikan Kecakapan Hidup Perempuan yang dilengkapi dengan teknologi informasi; 2) Masyarakat memiliki pengetahuan, keterampilan, dan pengembangan sikap yang positif sehingga memiliki kualitas hidup yang baik; 3) Tersedianya layanan informasi dan sumber akses informasi kepada masyarakat yang berkaitan dengan pendidikan, sosial budaya, seni, hukum, ekonomi (pertanian, perikanan, perdagangan), kesehatan dan teknologi-informasi. ${ }^{21}$

\section{Konsep Pengembangan Keterampilan Berwirausaha}

Menurut Mulyadi Nitisusastro, pengembangan adalah upaya yang dilakukan oleh pemerintah, pemerintah daerah, dunia usaha dan masyarakat untuk memberdayakan usaha mikro kecil, dan menengah melalui fasilitas bimbingan pendampingan dan bantuan penguatan untuk menumbuhkan dan meningkatkan kemampuan dan daya saing usaha mikro, kecil, dan menengah. Arti kata entrepreneur menurut Abraham Lembang, secara etimologis berasal dari bahasa Perancis yaitu entrepreneuse jika diterjemahkan berarti mencoba hal-hal yang baru. ${ }^{22}$ Kewirausahaan merujuk pada sifat, watak, dan ciri-ciri yang melekat pada seseorang yang mempunyai kemampuan menggunakan sumber daya (money, materials, man, machine) untuk menghasilkan gagasan inovatif ke dalam dunia usaha.Kewirausahaan merupakan suatu kemampuan dalam hal menciptakan kegiatan usaha. Kemampuan menciptakan ini

\footnotetext{
${ }^{20}$ Dit. Bindiktara, op.cit. h. 9

${ }^{21}$ Ibid, h. 9.

${ }^{22}$ Abraham Lembang. (2011). Who Wants to be an Option Entrepreneur. Jakarta:PT Gramedia Pustaka Utama.
} 
memerlukan kreativitas dan inovasi yang terus menerus untuk menemukan sesuatu yang berbeda. Seorang wirausahawan selalu berpikir untuk mencari, memanfaatkan dan menciptakan peluang usaha yang dapat memberikan keuntungan.

Beberapa sikap yang harus dimiliki wirausaha yaitu: 1) Percaya diri (self confidence): percaya diri merupakan keyakinan seseorang dalam menghadapi pekerjaan, yang bersifat internal, sangat relatif dan dinamis. Kepercayaan diri akan mempengaruhi gagasan, inisiatif, kreativitas, keberanian, semangat kerja, dan kegairahan berkarya, 2) Berorientasi tugas dan hasil: seorang yang mengutamakan tugas dan hasil adalah orang yang selalu mengutamakan nilai-nilai motif berprestasi, berorientasi pada laba, ketekunan, dan kerja keras, 3) Keberanian mengambil resiko: wirausaha adalah orang yang lebih menyukai usahausaha yang lebih menantang untuk mencapai kesuksesan. Kemampuan untuk mengambil resiko tergantung dari keyakinan pada diri sendiri, kesediaan untuk menggunakan kemampuan dalam mencari peluang, dan kemampuan untuk menilai situasi resiko secara realitis, 4) Kepemimpinan: seorang wirausaha harus memiliki sifat kepemimpinan, kepeloporan, dan keteladanan, 5) Berorientasi ke masa depan: wirausaha harus memiliki perspektif dan pandangan ke masa depan dengan kemampuan untuk menciptakan suatu yang baru dan berbeda, dan 6) Kreativitas dan inovasi: kewirausahaan adalah berfikir dan bertindak sesuai yang baru atau berfikir sesuai yang lama dengan cara baru. ${ }^{23}$

Menurut Rusdiana manfaat yang dapat diperoleh melalui berwirausaha adalah: 1) Memiliki kebebasan untuk mengaktualisasi potensi yang dimiliki. Banyak wirausaha yang berhasil mengelola usahanya karena menjadikan keterampilan atau hobi menjadi suatu pekerjaan, 2) Memiliki peluang untuk berperan bagi masyarakat, 3) Dengan berwirausaha seseorang memiliki kesempatan untuk berperan bagi masyarakat dengan menciptakan produk yang dibutuhkan masyarakat, dan 4) Dapat menjadi motivasi tersendiri untuk memulai berwirausaha. $^{24}$

Berdasarkan pendapat di atas, maka dapat disimpulkan bahwa manfaat dari kewirausahaan adalah berusaha memberikan bantuan kepada orang lain dan pembangunan sosial sesuain dengan kemampuannya, menambah daya tampung tenaga kerja sehingga dapat

\footnotetext{
${ }^{23}$ Basrowi. (2011). Kewirausahaan untuk Perguruan Tinggi. Bogor: Ghalia Indonesia.

${ }^{24}$ Rusdiana. (2012). Kewirausahaan: Teori dan Praktik. Surakarta: Pustaka Setia.
} 
mengurangi pengangguran, dan memberikan motivasi bagaimana harus kerja keras dan tekun dalam berwirausaha.

\section{PENUTUP}

Perempuan marginal sangat rentan mengalami masalah sosial, dan sangat beresiko secara sosial. Memberdayakan perempuan marginal melalui jalur pendidikan adalah sebuah merupakan upaya mobilisasi sosial baik vertikal maupun horisontal pada perempuan marginal. Menarik dan mengeluarkan perempuan dari kemarginalan yang dialami, menjadi pintu mulia untuk membantu perempuan lebih berdaya, bermartabat, baik secara sosial maupun ekonomi.

Program pendidikan kecakapan hidup dalam mengembangkan keterampilan berwirausaha dilakukan melalui berbagai macam kegiatan seperti peningkatan akses perempuan terhadap pengetahuan dan keterampilan tentang kewirausahaan dan pengembangan usaha. Hasil dari program pemberdayaan harus membentuk individu atau masyarakat menjadi mandiri. Program pemberdayaan melalui kewirausahaan seharusnya dapat membuat perempuan peserta program yang awalnya hanya menjadi ibu rumah tanggadan buruh dapat berwirausaha dan menambah pendapatan keluarga.

\section{DAFTAR RUJUKAN}

Abraham Lembang. (2011). Who Wants to be an Option Entrepreneur. Jakarta: PT Gramedia Pustaka Utama.

Agnes Sumartiningsih. (2004). Pembangunan Masyarakat Desa melalui InstitusiLokal. Yogyakarta: Aditya Media.

Agung U, Titin H. Model Pemberdayaan Perempuan Miskin Melalui Pelatihan Kewirausahaan Berbasis Potensi Lokal di Kecamatan Wedi Kabupaten klaten. Jurnal Penelitian Humaniora, Vol. 19, No.2, Oktober 2014: 154-167

Ambar Teguh Sulistiyani. (2004). Kemitraan dan Model-Model Pemberdayaan. Yogyakarta: Gava Media.

Amin Kuncoro dan Kadar, Pengaruh Pemberdayaan Perempuan dan Peningkatan Sumber Daya Ekonomi Keluarga, Buana Gender, LP2M IAIN Surakarta, Vol. 1 No. 1, JanuariJuni 2016, ISSN: 2527-8096.

Andi Hanindito. (2011). Berdaya Bersama Perempuan Indonesia. Jakarta:Kementrian Sosial RI. 
Basrowi. (2011). Kewirausahaan untuk Perguruan Tinggi. Bogor: Ghalia Indonesia.

Chatarina Rusmiyati. (2011). Pemberdayaan Remaja Putus Sekolah. Yogyakarta: B2P3KS Press.

Claros, Augusto Lopez dan Saadia Zahidi. 2005. Woman Empowerment : Measuring The Global Gender Gap. Worl Economic Forum. Diakses dari situs : www.weforum.org

Dik.Bindiktara. (2016). Petunjuk Teknis Program Pendidikan Kecakapan Hidup Perempuan. Jakarta: Dik.Bindiktara.

Eli Yuliawati. (2010). Pemberdayaan Kaum Perempuan dalam MenunjangPeningkatan Pendapatan Keluarga melalui Home Industry di Dusun Pelemadu, Desa Sriharjo, Kecamatan Imogiri, Kabupaten Bantul, DIY. Skripsi. Diakses dari eprints.uny.ac.id/7803/1/1-07404244051.pdf.padatanggal 18 Mei 2014.

Rusdiana. (2012). Kewirausahaan: Teori dan Praktik. Surakarta: Pustaka Setia.

Sulikanti Agusni,. Kebijakan dan Strategi Peningkatan produktifitas Ekonomi Perempuan, Kementerian Pemberdayaan Perempuan dan Perlindungan Anak Republik Indonesia, 2012, h. 13.

Susilorini, E. S. Evaluasi Program Pemberdayaan Ekonomi Perempuan Miskin di Kabupaten Ngawi, Media Soerje, Vol. 15 No. 2, Oktober 2014, ISSN: 1978-6239. 